\title{
Avoiding bio-perversity from carbon sequestration solutions
}

\author{
David B. Lindenmayer ${ }^{1,2}$, Kristin B. Hulvey ${ }^{3}$, Richard J. Hobbs ${ }^{3,4}$, Mark Colyvan $^{4}$, Adam Felton $^{5}$, \\ Hugh Possingham ${ }^{2}$, Will Steffen ${ }^{6}$, Kerrie Wilson ${ }^{2}$, Kara Youngentob $^{1}$, \& Philip Gibbons ${ }^{1}$ \\ ${ }^{1}$ Fenner School of Environment and Society and ARC Centre of Excellence for Environmental Decisions, The Australian National University, Canberra, \\ ACT 0200, Australia \\ ${ }^{2}$ ARC Centre of Excellence for Environmental Decisions, The University of Queensland, Brisbane, Queensland 4072, Australia \\ ${ }^{3}$ School of Plant Biology and ARC Centre of Excellence for Environmental Decisions, The University of Western Australia, 35 Stirling Highway, Crawley, \\ WA 6009, Australia \\ 4 Sydney Centre for the Foundations of Science, A14 Main Quadrangle, University of Sydney, Sydney, NSW 2006, Australia \\ ${ }^{5}$ Southern Swedish Forest Research Centre, Swedish University of Agricultural Sciences, Box 49, SE-230 53 Alnarp, Sweden \\ ${ }^{6}$ ANU Climate Change Institute, The Australian National University, Canberra, ACT 0200, Australia
}

\author{
Keywords \\ Altered ecosystem processes; biodiversity; \\ bio-perversity; carbon economy; invasive tree \\ species; land clearing; large-scale tree \\ plantations.

\section{Correspondence} \\ David B. Lindenmayer, Fenner School of \\ Environment and Society, The Australian \\ National University, Canberra, ACT 0200, \\ Australia. Tel: +61-(0)2-61250654; fax: \\ +61-(0)2-61250757. \\ E-mail: david.lindenmayer@anu.edu.au

\section{Received} \\ 10 July 2011 \\ Accepted \\ 14 November 2011 \\ Editor \\ Dr. Jos Barlow
}

doi: 10.1111/j.1755-263X.2011.00213.x

\begin{abstract}
The development of a new carbon economy has the potential to offer win-win outcomes for environments and economies. Large-scale tree plantations are expected to play a major role in carbon economies but could have negative ecological and economic consequences when key environmental values such as biodiversity conservation are not considered. We discuss three potential "bio-perversities" — negative outcomes for biodiversity-that could result from inappropriate plantation tree programs aimed solely at reducing atmospheric carbon dioxide and mitigating rapid climate change effects. These are: (1) clearing native vegetation to establish tree plantations, (2) planting trees that become invasive taxa, and (3) tree plantations negatively affecting key ecosystem processes such as fire and hydrological regimes. These bio-perversities may result from common mistakes in environmental management: (1) too narrow a focus on a single environmental value, (2) failing to adequately quantify ecological uncertainty, and (3) failing to anticipate how different groups of people respond to an environmental problem. We highlight ways to prevent possible bio-perverse outcomes in large-scale plantation programs. These include requiring that risk assessments precede project establishment, full carbon accounting is undertaken, incentives used to stimulate tree plantation establishment are rigorously examined, and rigorous compliance and ecological monitoring is undertaken.
\end{abstract}

Bio-perversity-negative biodiversity and environmental outcomes arising from a narrow policy and management focus on single environmental problems without consideration of the broader ecological context.

\section{Introduction}

Emissions of carbon dioxide and other greenhouse gases are the major drivers of recent changes in the earth's climate (IPCC 2007). As part of efforts to tackle this problem, economic instruments such as carbon taxes and carbon trading markets are leading to the development of a carbon economy (Galatowitsch 2009; Hamilton et al. 2010; Garnaut 2011). Income from carbon offsetting has the potential to drive major land management changes as land owners shift land to higher carbon storage states through alteration of farming methods or transformation of vegetation cover (e.g., Grainger et al. 2009; Fargione et al. 2010; Paoli et al. 2010). Indeed, the development of a carbon economy has the potential to create win-win environmental outcomes (Danielsen et al. 2009; Venter et al. 2009) such as the ecological restoration of cleared land (Galatowitsch 2009) with subsequent improvements in other values like biodiversity conservation (Bekessy \& Wintle 2008). Conversely, a narrow focus on carbon storage has the potential to create negative 
environmental outcomes if the protection and enhancement of other values such as biodiversity are not explicitly considered (Grainger et al. 2009; Putz \& Redford 2009; Harvey et al. 2010; Paoli et al. 2010).

Several mitigation strategies have been proposed as part of efforts to tackle climate change. A prominent one is to sequester carbon into the terrestrial biosphere by establishing plantations of trees (e.g., Strengers et al. 2007; Hamilton et al. 2010). For the purposes of this paper, which is focused on plantation initiatives to sequester carbon, we define tree plantations as: "Stands of trees of native or exotic species that are specifically created by the regular placement of cuttings, seedlings, or seed through human management. Tree plantations are managed for an economic purpose such as the sequestration of carbon for future economic benefit but also may include the extraction of timber or timber-related products" Plantations are typically comprised of one or a few fast-growing exotic tree species in even-aged and evenly spaced stands (Bauhus et al. 2010; FAO 2010).

We suggest that incentives to sequester carbon through limiting deforestation and forest degradation (Harvey et al. 2010; Paoli et al. 2010) as well as through establishing plantations (Strengers et al. 2007; Bauhus et al. 2010) are likely to increase as the impacts of climate change become more pronounced and intense, and as ecological systems and processes are further modified by climate change (Steffen et al. 2009). In this article, we argue that harmful outcomes for biodiversity-what we term "bio-perversities" — can arise as unintended consequences from a range of efforts to reduce forest-based carbon emissions and enhance forest-based carbon sequestration. Perhaps the greatest of associated potential bio-perversities are those, which may arise from ill-conceived or inappropriate large-scale plantation tree establishment projects. We provide examples where bioperversity may arise from plantation tree establishment, and identify approaches to avoid such outcomes in the context of an emerging carbon market.

\section{Tree plantations in global carbon sequestration}

Plantations encompass a wide range of models from small, species-diverse plantings that provide services additional to carbon sequestration, to large monocultures that focus solely on the production of wood and carbon sequestration. The characteristics of these plantations including the other resources produced (e.g., timber), plantation size, and species composition all help to determine how they will both integrate with, as well as affect, surrounding ecosystems. Of the $\sim 140$ million hectares of plantation trees existing in 2005, at least $20 \%$ generated ecosystem services in addition to timber production (including carbon sequestration; Kanninen 2010). A survey of 226 carbon projects across 40 countries indicated the majority were in tropicalmoist forests or temperate coniferous forests, followed by temperate broadleaf/mixed forests (Hamilton et al. 2010). The largest reported project areas were in Africa, Latin America, and Asia (795,015 ha, 669,952 ha, and 196,744 ha, respectively), with $76 \%$ using predominately native species $(>85 \%$ of project area planted with indigenous species), $18 \%$ using mixes, and $6 \%$ using predominately nonnative species $(>85 \%$ of project area planted with exotic species; Hamilton et al. 2010). Several carbonoffset markets consider ecosystem service benefits in addition to carbon sequestration as part of certification schemes (Ebeling \& Fehse 2009; Hamilton et al. 2010).

\section{Drivers of bio-perverse outcomes and their potential prominence in carbon plantation projects}

Interventions in complex ecosystems often result in perverse outcomes-that is, paradoxical and unintended negative consequences (Tenner 1996; Hobbs et al. 2011). Examples include the impacts of biocontrol organisms on native species (e.g., the Southwestern Willow Flycatcher Empidonax traillii extimus; Hultine et al. 2010), trophic cascades triggered by the removal of species from ecosystems (Estes et al. 2011), and management practices leading to increased threat of high severity fires due to the accumulation of fuels (Arno \& Fiedler 2005; Lindenmayer et al. 2011).

Bio-perverse outcomes from attempted solutions to ecological problems have a number of common characteristics, but if these are addressed at the outset of policy formation or project planning, managers may avoid associated problems. These characteristics include a narrow focus on a single ecosystem value or service, failure to accurately quantify ecological uncertainty, and failure to anticipate management responses to environmental regulations or incentives. In the case of plantation tree establishment, political, economic, and ecological factors increase the likelihood that one or more of these problems may occur.

\section{Too narrow a focus on one ecosystem value or service}

As a society, we benefit from a portfolio of environmental processes, goods, and services, with greenhouse gas 
reduction just one of many desired outcomes from environmental programs and policies. A narrow focus on carbon sequestration that ignores other societal values can lead to suboptimal management decisions and policy outcomes (Grainger et al. 2009; Harvey et al. 2010; Paoli et al. 2010). In particular, because resources for the development and implementation of programs and regulations are often scarce, from a cost-benefit perspective, a narrow focus on one ecosystem value can result in missed opportunities to achieve multiple desired outcomes (Paoli et al. 2010). A focus on portfolios of valued ecosystem attributes in plantations, including biodiversity and additional ecosystem goods and services, can leverage time and resources for program creation and result in solutions that optimize the production of multiple valued services (Phelps et al. 2011).

We argue that incentives to establish large-scale tree plantations for carbon sequestration should incorporate other values (Diaz et al. 2009) including the maintenance of key ecosystem processes (e.g., see Cao 2008) and the provision of habitat for biodiversity-such as in recent REDD+ projects (Convention on Biological Diversity 2011).

\section{Failure to accurately quantify ecological uncertainty}

A myriad of processes including abiotic factors and interactions among individual species at a range of spatial and temporal scales can make the management of ecosystems intrinsically complex. Managers of plantations for carbon sequestration need to understand how interactions between species affect carbon uptake and storage in multiple carbon pools, most notably plant biomass and soils. They must understand how disturbances such as catastrophic events (e.g., wildfires) and long-term processes (e.g., climate variability and climate change) might affect tree growth and longevity (e.g., see examples from China; Cao 2008). There also needs to be greater recognition of the ways in which plantations can influence biotic and abiotic conditions in neighboring areas.

This complexity necessitates responsible treatment of uncertainty in environmental decision-making via risk assessment and options-scoping in plantation tree projects (Regan et al. 2002; Halpern et al. 2006) for a systematic treatment and practical examples of environmental uncertainties.

\section{Failure to anticipate management responses to environmental regulations or incentives}

The creation of new environmental regulations may yield unforseen negative outcomes arising from stakeholders'
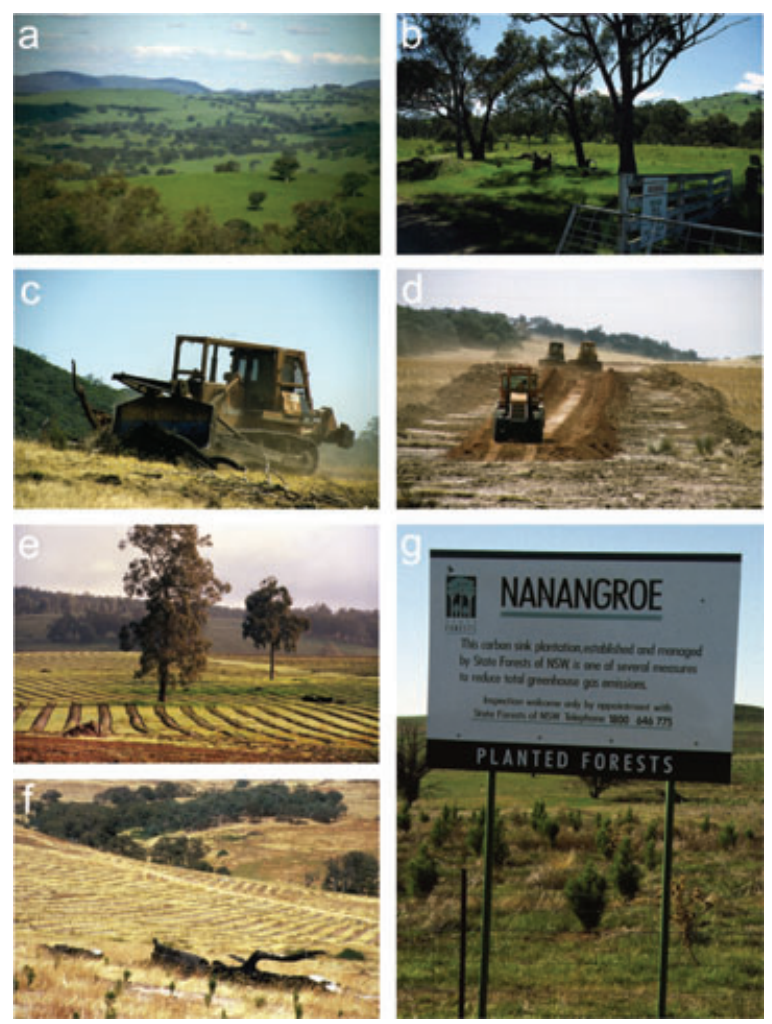

Figure 1 Native woodland removal in southeastern Australia on semicleared agricultural land (a-d), followed by the establishment of a Radiata Pine (Pinus radiata) plantation (e,f). This plantation was established for paper pulp and timber production, but also was claimed as a carbon offset (g). Patches of temperate woodland support large numbers of declining bird species and such vegetation types have been listed as threatened ecological communities since vegetation clearing for plantation establishment in this image. The sign shown in (g) reads: "This carbon sink plantation, established and managed by State Forests of NSW, is one of several measures to reduce total greenhouse gas emissions". (Photos by David Lindenmayer)

decisions on how to meet new rule obligations or incentives (e.g., Garcia et al. 2009). Bio-perverse outcomes might arise if, for example, reward systems fail to distinguish between native and nonnative plantings, leading plantation growers to establish introduced species that may spread into surrounding land. In addition, poorly designed incentives might encourage replacement of existing native forests with plantations thereby leading to land conversion and biodiversity loss (Grainger et al. 2009)as has occurred on the Tiwi Islands in northern Australia and also in parts of southern Australia (see Figures 1 and 2; Crowley et al. 2011). In a carbon sequestration context, it is critical to anticipate the different strategies that might be adopted by plantation growers to a particular policy and to create appropriate incentives that best achieve a range of ecologically desirable environmental outcomes (Grainger et al. 2009; Colyvan et al. 2011). 


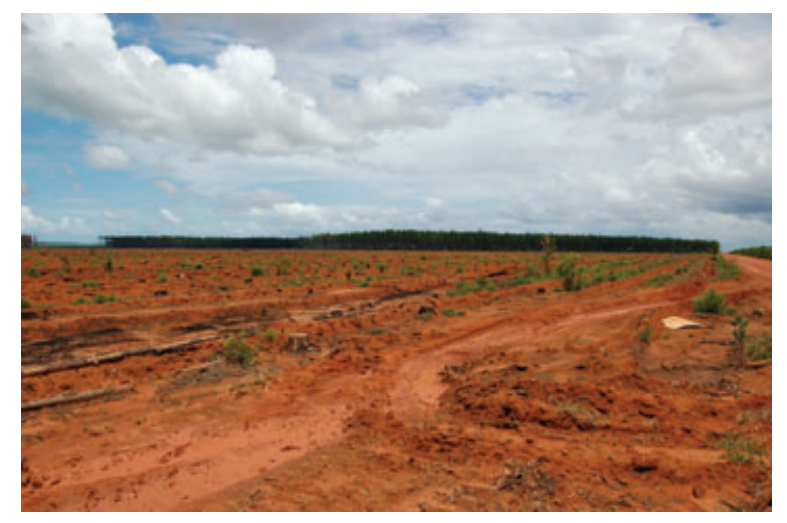

Figure 2 Clearing for plantation forestry on the Tiwi Islands. Plantation forestry requires the total clearance of native vegetation before the timber species are planted. (Photo by Charles Roche, Environment Centre NT)

\section{Potential bio-perversities stemming from plantation tree programs designed to sequester carbon and ways to avoid them}

Several authors have outlined some of the ways that bioperverse outcomes may arise from the establishment of carbon economies. For example, Phelps et al. (2011) discuss how future carbon markets are likely to seek lowestcost emissions reductions (such as from plantations) and are thus unlikely to seek REDD+ investments that integrate additional ecosystem services at increased costs. Grainger et al. (2009) have described how REDD+ investments in forests that deliver the greatest carbon benefits may direct funding away from traditional conservation priority sites. A further issue is what has been termed "leakage" (e.g., see Oliveira et al. 2007) in which increased conservation efforts in one area (e.g., through initiatives like REDD+) may lead to pressure to convert native vegetation to plantations in other areas, thereby resulting in significant losses of biodiversity (Grainger et al. 2009). Paoli et al. (2010) describe the risks of such bio-perverse outcomes in Indonesian peat swamp and mineral soil forests as one example.

In the following sections, we discuss three potential bio-perverse outcomes arising from carbon sequestration plantations: (1) land clearing to establish tree plantations, (2) the risks of plantation trees becoming invasive plants, and (3) the potential for plantations to negatively affect key ecological processes and disturbance regimes. These threats reflect some of the well-documented proximate causes of biodiversity loss globally; viz: habitat loss, invasive species, and threats from human-altered ecosystem processes (Millennium Ecosystem Assessment 2005).
We suggest that four mitigation strategies will be important to avoid the three key forms of bio-perversity outlined above. First, it will be essential to conduct risk assessments of ecological impacts. These would include: (1) An evaluation of the risks to existing ecosystems. For example, how likely is a plantation to change fire regimes resulting in decreases in biodiversity both within and adjacent to plantations? (2) An assessment of uncertainties in understanding of ecosystem processes. For instance, do we know how an introduced tree species will spread in a particular environment and location? And (3) An evaluation of tradeoffs between the ecosystem services gained and lost through plantation establishment. For example, are the benefits from carbon-offsets created on-site in a plantation balanced by the negative impacts on water regimes occurring on and off the plantation? Will the total amount of carbon sequestered in a newly established plantation equal the amount lost in the clearing of the forest it replaced? Many negative effects of plantations occur offsite and therefore evaluation of risks, uncertainties, and tradeoffs should not stop at the boundaries of a plantation, but should extend to surrounding areas.

A second important strategy to prevent bio-perverse outcomes will be to conduct full carbon accounting of ecosystems and proposed management activities. This would include quantifying the amount of carbon to be sequestered in plantations over a target time period relative to the ecosystems they replace, and would account for all emissions associated with plantation establishment (e.g., land clearing, burning, tree propagation, transportation) and plantation management (e.g., road construction and timber haulage).

A third mitigation strategy will be to thoroughly examine the incentives used to stimulate the establishment of tree plantations. This includes anticipating the different strategies that might be adopted by plantation growers to a particular policy, and should involve collaboration with local and regional policy-makers (those familiar with local governance systems) as well as ecologists (those familiar with local ecosystems). One aim would be to create incentives that broaden plantation goals beyond carbon sequestration to include a range of ecologically desirable environmental outcomes, including the maintenance of biodiversity (e.g., REDD+; Convention on Biodiversity 2011). However, we fully recognize the significant practical challenges to incorporating noncarbon ecosystem services (e.g., defining and quantifying biodiversity), as well as to funding the additional costs associated with monitoring and reporting on ecosystem services for which there are currently limited or no markets (Ebeling \& Fehse 2009; Phelps et al. 2011). On this basis, Grainger et al. (2009) suggest an investment role in these areas for the considerable amount of "nonmarket 
funds" such as those from foreign aid, pollution permits, and private conservation funding.

A fourth strategy for avoiding bio-perverse outcomes will be to establish compliance and ecological monitoring programs (sensu Lindenmayer \& Likens 2010) to detect bio-perverse outcomes. Such programs should include both local level "participatory" monitoring as well as subnational (regional) and national level "expert-based" monitoring (see Pistorius et al. 2010). Both kinds of monitoring at different scales would be critical for providing feedback to policy-makers and investors to alter incentive schemes and management practices to limit the risks of bio-perversity. However, significant challenges remain with respect to funding such monitoring programs (Ebeling \& Fehse 2009) as well as the development of robust ways to integrate data and insights from the different kinds of monitoring conducted at different scales (see Lindenmayer \& Likens 2010).

\section{Avoiding bio-perverse land and natural forest clearing}

Habitat modification is one of the greatest threats to biodiversity globally (Lindenmayer \& Fischer 2006; Vié et al. 2009). Studies of the impacts of plantation tree establishment in environments such as temperate woodlands, native grasslands, and tropical forests demonstrate that vegetation conversion to densely stocked plantations of trees results in substantial losses of suitable habitat for a wide range of species (Tyndale-Biscoe \& Smith 1969; Lindenmayer et al. 2008). For example, Harvey et al. (2010) have expressed concern about the potential for bio-perversity resulting from initiatives like REDD through promoting the establishment of Oil Palm (Elaeis guineensis) plantations which have limited value for biodiversity conservation. They highlighted the need to ensure that natural forest and nonforest systems are not converted to plantations (Harvey et al. 2010). The risks of conversion of natural vegetation to plantations might be particularly pronounced in relatively low carbon environments like native grasslands and shrublands (see Figure 1)-similar to what has occurred throughout large areas in China (Xu 2011) and in the South American biofuels industry (e.g., the conversion of formerly Cerradodominated vegetation; Mendonça 2011). As a result, although tree plantations can deliver some valuable ecosystem services (e.g., timber, fuel, food) and can sometimes have surprising value for some elements of the biota (e.g., Brockerhoff et al. 2008; Quine \& Humphrey 2010), they do not have biodiversity values or ecological functions equivalent to natural vegetation (Lindenmayer E Hobbs 2004; Barlow et al. 2007; Felton et al. 2010; Gibson et al. 2011).
The adoption of the four strategies outlined aboveecological risk assessment, full carbon accounting, better assessment of the incentives used to stimulate the establishment of tree plantations, and the establishment of appropriately scaled and integrated compliance and ecological monitoring programs-will all be important for avoiding bio-perverse outcomes from land clearing.

Full carbon accounting assessment of areas being considered for conversion to plantations will be of particular importance and it may demonstrate the carbon sequestration value of maintaining native forest or grassland compared with plantation tree establishment. As an example, several studies have shown that monocultures of plantation trees may take longer to produce a net carbon gain and ultimately store less carbon in aboveground biomass and soil organic carbon than native primary forests, secondary (regenerating) native forests, and multistrata agro-forestry plantings (Danielsen et al. 2009; Kanowski \& Catterall 2011). Forests with low tree diversity have also been shown to accumulate less carbon than forests with multiple tree species (Chen 2006). Exotic plantations have also been shown to deplete soil nutrients, and this may negatively affect the sustainability of carbon sequestration by reducing long-term productivity (Ewel et al. 1991). Accurate carbon accounting may indicate that plantation establishment will be best done on cleared agricultural lands of marginal economic value for farming or cropping (Lamb et al. 2001; Danielsen et al. 2009). Moreover, appropriately managed plantations in these areas might also mitigate problems like soil erosion and secondary salinity (Stirzaker et al. 2002) and promote conservation of some biota (Reino et al. 2010).

We suggest that appropriate definitions of forests and plantations are another absolutely critical part of avoiding bio-perverse land and natural forest clearing (Harvey et al. 2010). This is, in part, because nonforest environments can be classified as "forests" because they meet the structural definition of forests (Sasaki \& Putz 2009). Indeed, the United Nations Framework Convention on Climate Change (UNFCCC) makes no distinction between natural forest ecosystems (including primary forests) and plantations. Such a lack of distinction means that it is potentially permissible to clear a natural forest and replace it with a plantation that can eventually attain height and crown density equivalent to that of a natural forest. We suggest that major carbon-based agreements should employ a definition of a plantation not unlike the one used in this article (as described earlier) to differentiate such areas from natural forests.

As we outlined above, a careful examination of the incentives used to stimulate the establishment of tree plantations is crucial for preventing bio-perversity. Notably, the UNFCCC recently established a set of basic safeguards 
for REDD+, including one stating that REDD+ should not incentivize the replacement of existing forests (to establish plantations; see UNFCCC 2011). However, the UNFCC safeguards fall short of the precautions we identify as necessary. There are also related safeguards, both for the voluntary carbon market and under development for future REDD+ carbon markets as well as through the Convention on Biological Diversity; Climate, Community and Biodiversity Association (CCBA), and the Forest Stewardship Council (Harvey et al. 2010).

\section{Limiting bio-perverse species invasions from plantation trees}

The spread of invasive species is a widely recognized threat to biodiversity worldwide (Simberloff et al. 2010). The most frequently used species in plantations are quickgrowing trees from the genera Pinus, Eucalyptus, and Acacia (Doughty 2001) that are tolerant to a wide range of environmental conditions (Eldridge et al. 1994). When established outside their original range, some of these plantation tree species can become invasive. Bio-perverse outcomes from carbon sequestration plantation projects that result in invasive tree species may include biotic homogenization (Olden et al. 2004), genetic swamping (Barbour et al. 2010) and altered ecosystem processes (Simberloff et al. 2010). These sometimes irreversible invasions can often become costly to manage and lead to significant biodiversity loss (Richardson \& Rejmanek 2004).

The risks of plantation trees becoming invasive plants may be reduced through all four of the strategies outlined at the beginning of this section. Reward schemes need to be coupled with a formal risk assessment process to account for the possibility of plantation trees becoming invasive plants. Risk assessment might indicate, for example, the value of using native rather than exotic tree species in plantation programs if native trees provide superior habitats for biodiversity (Hartley 2002; Gries et al. 2011), and managers could receive payments for providing such habitat. Broadening the focus of plantation programs to include native tree species, however, may require tree plantations to be managed somewhat differently than has traditionally been the case in the past (Putz \& Redford 2009). Such management will require careful consideration of issues like the timing and frequency of thinning treatments to create habitat for wildlife (see Carey et al. 1999).

Ecological monitoring, both within and outside plantation estates, will also be an important strategy for limiting the risks of plantation trees becoming invasive. Early warnings of such problems significantly improve the chances that interventions to manage invasive species will be successful and cost-effective (McNeely et al. 2003).

\section{Minimizing bio-perverse changes in key ecosystem processes and disturbance regimes}

The modification of key ecosystem processes is well recognized as a major factor influencing biodiversity loss in many parts of the world. In particular, plantation establishment is suggested to have large impacts on hydrologic, geomorphologic and fire regimes both within plantations as well as in the surrounding landscapes. Plantation establishment has considerable potential to influence hydrologic cycles by altering water tables (Jackson et al. 2005). Such alterations can have profound effects on the landscape within and adjacent to plantations, resulting in compositional change of vegetation and losses of species richness (Farley et al. 2005; Cao 2008). Plantations of trees also may change fire regimes by introducing species that alter both flammability and fuel loads (e.g., Thompson et al. 2007). Altered fire frequency and severity may decrease native species richness both locally (Lindenmayer et al. 2008) and across landscape mosaics (Nelson et al. 2008).

Thorough, knowledge-based risk assessments of plantation projects and ecological monitoring will be essential for early detection and minimization of potential bio-perverse outcomes such as altered hydrologic and geomorphic cycles and altered fire regimes. Some locations will be deemed unsuitable for plantation establishment as a result of these considerations. It is imperative that incentives schemes and reward systems have clear regulations to prevent the establishment of plantations in regions that are unsuitable.

\section{Concluding comments}

The establishment of plantations of trees is a widely canvassed strategy for tackling climate change (e.g., Strengers et al. 2007; Hamilton et al. 2010), although to date only very few afforestation and reforestation projects commenced under initiatives like the Clean Development Mechanism within the United Nations Framework Convention on Climate Change (see Thomas et al. 2010).

We argue that narrowly focused large-scale plantations for carbon sequestration may produce a range of perverse environmental outcomes-bio-perversities. Three of these are clearing native vegetation to establish tree plantations, planted trees becoming invasive taxa, and tree plantations significantly altering key ecosystem processes. We argue that four strategies should be adopted 
to avoid these bio-perversities: ecological risk assessment, full carbon accounting, examination of incentives that stimulate tree plantation establishment, and establishment of compliance and ecological monitoring programs. Adoption of these strategies will allow us to actively seek the timely development and implementation of policies and standards aimed at minimizing bio-perverse outcomes.

Conversely, if the rush to plant trees and establish plantations for carbon sequestration results in a range of other environmental values being ignored, we may exacerbate existing environmental problems, contribute to further biodiversity loss, introduce additional obstacles to recovering or maintaining the ecological integrity of environments, and ultimately fail to mitigate the anthropogenic causes of climate change.

\section{Acknowledgments}

We thank Claire Shepherd for assistance in preparing this article. DBL thanks Professor B. Mackey, Dr. H. Keith and Dr. B. Azhar for collaborative efforts on projects related to the one reported here. RJH acknowledges support through an ARC Laureate Fellowship. Astute comments by Professor P. Levins and two anonymous referees greatly improved earlier versions of this manuscript.

\section{References}

Arno, S.F., Fiedler C.E. (2005) Mimicking nature's fire: restoring fire-prone forests in the West. Island Press, Washington, DC.

Barbour, R.C., Wise S.L., McKinnon G.E., Vaillancourt R.E., Williamson G.J., Potts B.M. (2010) The potential for gene flow from exotic eucalypt plantations into Australia's rare native eucalypts. Forest Ecol Manag 260, 2079-2087.

Barlow, J., Gardner T.A., Araujo I.S. et al. (2007) Quantifying the biodiversity value of tropical primary, secondary and plantation forests. Proc Natl Acad Sci USA 104, 1855518560.

Bauhus, J., van der Meer P., Kanninen M. (2010) Ecosystem goods and services from plantation forests. CSIRO Publishing, Melbourne.

Bekessy, S.A., Wintle B.A. (2008) Using carbon investment to grow the biodiversity bank. Conserv Biol 22, 510-513.

Brockerhoff, E., Jactel H., Parrotta J.A., Quine C.P., Sayer J. (2008) Plantations and biodiversity: oxymoron or opportunity? Biodivers Conserv 17, 925-951.

Cao, S. (2008) Why large-scale afforestation efforts in China have failed to solve the desertification problem. Environ Sci Technol 42, 1826-1831.

Carey, A.B., Lippke B.R., Sessions J. (1999) Intentional systems management: managing forests for biodiversity. J Sustain Forest 9, 83-125.
Chen, X. (2006) Tree diversity, carbon storage, and soil nutrient in an old-growth forest at Changbai Mountain, Northeast China. Commun Soil Sci Plant Anal 37, 363-375.

Colyvan, M., Justus J., Regan H.M. (2011) The conservation game. Biol Conserv 144, 1246-1253.

Convention on Biological Diversity. (2011) REDD-plus: Reducing emissions from deforestation and forest degradation and the role of conservation, sustainable management of forests and enhancement of forest carbon stocks in developing countries (REDD-plus). Available from: http://www.cbd.int/forest/redd/ Accessed 24 September 2011.

Crowley, G., Nou T., Westaway J. (2011) Management practices for wildlife conservation; Forestry and biofuels. Available from: http://www.landmanager.org.au/forestryand-wildlife-management (Accessed 15 September 2011).

Danielsen, F., Beukema H., Burgess N.D. et al. (2009) Biofuel plantations on forested lands: double jeopardy for biodiversity and climate. Conserv Biol 23, 348-358.

Diaz, S., Wardle D.A., Hector A. (2009) Incorporating biodiversity in climate change mitigation initiatives. Pages 149-166 in S. Naeem, D.E. Bunker, A. Hector, M. Moreau, C. Perrings, editors. Biodiversity, ecosystem functioning, and human wellbeing: an ecological and economic perspective. Oxford University Press, Oxford.

Doughty, R.W. (2001) The Eucalyptus. Johns Hopkins University Press, Baltimore, MD.

Ebeling, J., Fehse J. (2009) Challenges for a business case for a high-biodiversity REDD projects and schemes. A report for the Secretariat of the Convention of Biological Diversity (SCBD). Ecosecurities Limited, Dublin, Ireland.

Eldridge, K., Davidson J., Harwood C., van Wyk G. (1994) Eucalypt domestication and breeding. Clarendon Press, Oxford.

Estes, J.A., Terborgh J., Brashares J.S. et al. (2011) Trophic downgrading of planet earth. Science 333, 301-306.

Ewel, J.J., Mazzarino M.J., Berish C.W. (1991) Tropical soil fertility changes under monocultures and successional communities of different structure. Ecol Appl 1, 289-302.

FAO. (2010) Global Forest Resources Assessment 2010: Main report. FAO, Rome.

Fargione, J.E., Plevin R.J., Hill J.D. (2010) The ecological impact of biofuels. Annu Rev Ecol Syst 41, 379-406.

Farley, K.A., Jobbagy E.G., Jackson R.B. (2005) Effects of afforestation on water yield: a global synthesis with implications for policy. Glob Change Biol 11, 1565-1576.

Felton, A., Knight E.J., Wood J.T., Zammit C., Lindenmayer D.B. (2010) A meta-analysis of fauna and flora species richness and abundance in plantations and pasture lands. Biol Conserv 143, 545-554.

Galatowitsch, S.M. (2009) Carbon offsets as ecological restorations. Restor Ecol 17, 563-570.

Garcia, C.A., Bhagwat S.A., Ghazoul J. et al. (2009) Biodiversity conservation in agricultural landscapes: challenges and opportunities if coffee agroforests in the Western Ghats, India. Conserv Biol 24, 479-488. 
Garnaut, R. (2011) The Garnaut Review 2011. Australia in the Global response to climate change. Cambridge University Press, Melbourne.

Gibson, L., Lee M.L., Koh L.P. et al. (2011) Primary forests are irreplaceable for sustaining tropical biodiversity. Nature 478, 378-381.

Grainger, A., Boucher D.H., Frumhoff P.C. et al. (2009) Biodiversity and REDD at Copenhagen. Curr Biol 19, R974-R976.

Gries, R., Louzada J., Almeida S., Macedo R., Barlow J. (2011) Evaluating the impacts and conservation value of exotic and native tree afforestation in Cerrado grasslands using dung beetles. Insect Conserv Divers doi:10.1111/j.1752-4598.2011.00145.x.

Halpern, B., Regan H.M., Possingham H.P., McCarthy M. (2006) Accounting for uncertainty in marine reserve design. Ecol Lett 9, 2-1 1.

Hamilton, K., Chokkalingam U., Bendana M. (2010) State of the forest Carbon markets 2009: taking root and branching out. Forest Trends, Washington, DC.

Hartley, M.J. (2002) Rationale and methods for conserving biodiversity in plantation forests. Forest Ecol Manag 155, 81-95.

Harvey, C.A., Dickson B., Kormos C. (2010) Opportunities for achieving biodiversity conservation through REDD. Conserv Lett 3, 53-61.

Hobbs, R.J., Hallett L.M., Ehrlich P.R., Mooney H.A. (2011) Intervention ecology: applying ecological science in the 21 st century. BioScience 61, 442-450.

Hultine, K.R., Belnap J., van Riper C. et al. (2010) Tamarisk biocontrol in the western United States: ecological and societal implications. Front Ecol Environ 8, 467-474.

IPCC. (2007) Climate change 2007: The physical science basis. Contribution of Working Group 1 to the Fourth Assessment Report of the Intergovernmental Panel on Climate Change. Pages 996 in S. Solomon, D. Qin, M. Manning, Z. Chen, M. Marquis, K. Avery et al., editors. Cambridge University Press, Cambridge, UK and New York, USA.

Jackson, R.B., Jobbagy E.G., Avissar R. et al. (2005) Trading water for carbon with biological sequestration. Science $\mathbf{3 1 0}$, 1944-1947.

Kanninen, M. (2010) Plantation forests: global perspectives. Pages $1-15$ in J. Bauhus, P. van der Meer, M. Kanninen, editors. Ecosystem Goods and Services from Plantation Forests. CSIRO Publishing, Melbourne.

Kanowski J., Catterall C.P. (2011) Carbon stocks in above-ground biomass of monoculture plantations, mixed species plantations and environmental restoration plantings in north-east Australia. Ecol Restor Manag 11, 119 126.

Lamb, D., Keenan R., Gould K. (2001) Historical background to plantation development in the tropics: a north Queensland case study. Pages 9-20 in J.L. Herbohn, editor. Sustainable Farm Forestry in the Tropics. Edward Elgar, Cheltenham.
Lindenmayer, D.B., Cunningham R.B., MacGregor C. et al. (2008) Temporal changes in vertebrates during landscape transformation: a large-scale "natural experiment". Ecol Monogr 78, 567-590.

Lindenmayer, D.B., Fischer J. (2006) Habitat fragmentation and landscape change. Island Press, Washington, DC.

Lindenmayer, D.B., Hobbs R.J. (2004) Fauna conservation in Australian plantation forests - a review. Biol Conserv 119, 151-168.

Lindenmayer, D.B., Hobbs R.J., Likens G.E., Krebs C., Banks S.C. (2011) Newly discovered landscape traps produce regime shifts in wet forests. Proc Natl Acad Sci USA 108, 16863-16864.

Lindenmayer, D.B., Likens G.E. (2010) Effective ecological monitoring. CSIRO Publishing and Earthscan, Melbourne and London.

McNeely, J.A., Neville L.E., Rejmanek M. (2003) When is eradication a sound investment? Conserv Practice 4, 30-41.

Mendonça, M. (2011) Monocropping for agrofuels: the case of Brazil. Development 54, 98-103.

Millennium Ecosystem Assessment. (2005) Ecosystems and human well-being: biodiversity synthesis. World Resources Institute, Washington, DC.

Nelson, J.L., Zavaleta E.S., Chapin F.S. (2008) Boreal fire effects on subsistence resources in Alaska and adjacent Canada. Ecosystems 11, 156-171.

Olden, J.D., LeRoy Poff N., Douglas M.R., Douglas M.E., Fausch K.D. (2004) Ecological and evolutionary consequences of biotic homogenization. Trends Ecol Evol 19, $18-24$.

Oliveira, P., Asner G. P., Knapp D. et al. (2007) Land-use allocation protects the Peruvian Amazon. Science 317, 1233-1236.

Paoli, G.D., Wells P.L., Meijaard E. et al. (2010) Biodiversity conservation in the REDD. Carbon Balance Manage 5, 7.

Phelps, J., Webb E.L., Koh L.P. (2011) Risky business: an uncertain future for biodiversity conservation finance through REDD+. Conserv Lett 4, 88-94.

Pistorius, T., Schmitt C.B., Benick D., Entenmann S. (2010) Greening REDD+. Challenges and opportunities for forest biodiversity conservation. Institute of Forest and Environmental Policy, University of Freiberg, Freiberg, Germany.

Putz, F.E., Redford K.H. (2009) Dangers of carbon-based conservation. Global Environ Chang 19, 400-401.

Quine, C.P., Humphrey J.W. (2010) Plantations of exotic trees in Britian: irrelevant for biodiversity or novel habitat for native species? Biodivers Conserv 19, 1503-1512.

Regan, H.M., Colyvan M., Burgman M.A. (2002) A taxonomy and treatment of uncertainty for ecology and conservation biology. Ecol Appl 12, 618-628.

Reino, L., Porto M., Morgado R., Carvalho F., Mire A., Beja P. (2010) Does afforestation increase bird nest predation risk in surrounding farmland? Forest Ecol Manag 260, 1359-1366. 
Richardson, D.M., Rejmanek M. (2004) Conifers as invasive aliens: a global survey and predictive framework. Divers Distrib 10, 321-331.

Sasaki, N., Putz F.E. (2009) Critical need for new definitions of "forest" and "forest degradation" in global climate change agreements. Conserv Lett 2, 226-232.

Simberloff, D., Nunez M.A., Ledgard N.J. et al. (2010) Spread and impact of introduced conifers in South America: Lessons from other southern hemisphere regions. Austral Ecol 35, 489-504.

Steffen, W., Burbidge A., Hughes L. et al. (2009) Australia's biodiversity and climate change. CSIRO Publishing, Melbourne.

Stirzaker, R., Vertessey R., Sarre A., editors. (2002) Trees, water and salt. An Australian guide to using trees for healthy catchments and productive farms. Joint Venture Agroforestry Program, Canberra.

Strengers, B.J., van Minnen J.G., Eickhout B. (2007) The role of carbon plantations in mitigating climate change: potentials and costs. Clim Change $\mathbf{8 8}$, 343-366.

Tenner, E. (1996) Why things bite back: predicting the problems of progress. Fourth Estate, London.
Thomas, S., Dargusch P., Harrison S., Herbohn J.L. (2010) Why are there so few afforestation and reforestation Clean Development Mechanism projects? Land Use Policy 27, 880-887.

Thompson, J.R., Spies T.A., Ganio L.M. (2007) Reburn severity in managed and unmanaged vegetation in a large wildfire. Proc Natl Acad Sci USA 104, 10,743-10,748.

Tyndale-Biscoe, C.H., Smith R.F.C. (1969) Studies of the marsupial glider, Schoinobates volans (Kerr) III. Response to habitat destruction. J Anim Ecol 38, 651-659.

United Nations Framework Convention on Climate Change (UNFCCC). (2011) Report of the conference of the parties on its sixteenth session, held in Cancun from 29 November to 10 December 2010: Appendix 1. United Nations.

Venter, O., Laurance W.F., Iwamura T., Wilson K.A., Fuller R.A., Possingham H.P. (2009) Harnessing carbon payments to protect biodiversity. Science 326, 1368.

Vié, J.-C., Hilton-Taylor C., Stuart S.N. (2009) Wildlife in a Changing World. An Analysis of the 2008 IUCN Red List of Threatened Species. International Union for Conservation of Nature and Natural Resources, Gland, Switzerland.

$\mathrm{Xu}, \mathrm{J}$. (2011) China's new forests aren't as green as they seem. Nature 477, 371. 